\title{
Acidity Control After Surface Application of Micronized Liming Material in a Typic Distrudept Under No-Tillage
}

\author{
Jéssica Alves Nogaroli ${ }^{*}$ \\ https://orcid.org/0000-0002-3184-6661
}

\author{
Adriel Ferreira da Fonseca ${ }^{2}$ \\ https://orcid.org/0000-0002-2773-3250
}

${ }^{1}$ Tuiuti of Paraná University, Faculty of Exact Sciences and Technology - Barigui Campus, Curitiba, Paraná, Brazil; ${ }^{2}$ State University of Ponta Grossa (UEPG), Department of Soil Science and Agricultural Engineering - Uvaranas Campus, Ponta Grossa, Paraná, Brazil.

Received: 2019.07.10; Accepted: 2019.12.12.

*Correspondence: jessica.nogaroli@utp.br; Tel.: +55-42-999652859 (F.L.)

\section{HIGHLIGHTS}

- The fineness particles of micronized liming do not favor the soil reaction in the 5-60 cm layer.

- The micronized liming increase $\mathrm{pH}$ values in the 0-5 $\mathrm{cm}$ layer, in an Inceptisol under no-tillage.

- The gap between the soil base saturation estimated and obtained is smaller with micronized liming.

- The liming materials not changed chemical attributes below the point of placement, in an Inceptisol.

\begin{abstract}
The objected to evaluate the $\mathrm{pH}$ and soil base saturation (V) values, during 45 months after, surface application and without incorporation of the liming materials in deeper layers of soil. The experimental design was completely randomized blocks in split-plot with four replications. In the plots were studied the dolomitic limestone (DL) and micronized liming materials (MLM) - granulated micronized calcite (GMC) and dolomite (GMD), and carbonated suspension (CS). In the subplots were studied doses of all the liming materials aiming to increase $\mathrm{V}$ to 50,70 and $90 \%$ besides of control treatment. We measured the $\mathrm{pH}$ and $\mathrm{V}$ values in $0-5,5-10,10-20,20-40$ and $40-60 \mathrm{~cm}$ soil layers over time (5, 15, 28, 37 and 45 months). The MLM were more efficient to increase and maintain the $\mathrm{pH}$ and $\mathrm{V}$, over time, than $\mathrm{DL}$. The doses of MLM aiming $\mathrm{V}$ to $50-70 \%$ increasing the $\mathrm{pH}$ and $\mathrm{V}$ of Typic Distrudept. Despite the MLM are more fineness than DL, the effectiveness for soil acidity control in subsoil were inefficient, because theses $\mathrm{pH}$ and $\mathrm{V}$ increases/maintains occurred just in 0-5 cm layer. However, the MLM present lower gap between the V estimated and obtained, in the $0-5 \mathrm{~cm}$ layer, than DL.
\end{abstract}

Keywords: soil reaction, soil with variable charge, soil base saturation, pelletized limes, fluid lime.

\section{INTRODUCTION}

Around $40 \%$ of the land used for agriculture in the world have their productivity limited by soil acidity [25]. The acidification occurs due to following factors: rainfall higher; basic cations displaced by $\mathrm{H}^{+}$; basic cations leached; use of nitrogen $(\mathrm{N})$ fertilizer and/or $\mathrm{N}$ fixation [12]; oxides-Al and oxides-Fe accumulation; higher aluminum (Al) and manganese $(\mathrm{Mn})$ concentration; release of $\mathrm{H}^{+}$from soil organic; $\mathrm{Al}$ and Fe hydrolysis; uptake of cations favoring extrusion of $\mathrm{H}^{+}[13,14]$; and acidity deposition by fossil fuel combustion [16]. 
Therefore, the soil acidity control is important for keeping of crop yield and reduce of soil fertility loss, mainly in variable charge soils (as Typic Distrudept).

In no-tillage (NT), the soil acidity control occurs with surface application of liming materials, without incorporation. Then, the reaction of the liming material in NT is lower and gradual [5], but can resulting, along the time in amelioration of the soil fertility below the point of placement [18]. The liming materials provide ideals conditions of change in the $\mathrm{pH}$ and exchange complex, favoring the crops yield and amelioration of soils attributes $[4,6]$. Besides, in soils with controlled acidity there is increase of crops yield due to carbon input [20] and this influence the soil reaction [13,14].

The liming materials more common employed for soil acidity control include calcite $\left(\mathrm{CaCO}_{3}\right)$, dolomite $\left(\mathrm{Ca}, \mathrm{Mg}\left(\mathrm{CO}_{3}\right)_{2}\right)$ and magnesite $\left(\mathrm{MgCO}_{3}\right)$ [4]. However, the common liming materials, as dolomitic limestone (DL), not presented faster dissolution than micronized liming material (MLM). These MLM can to control faster acidity and to be source of calcium and magnesium o soil-plant system $[10,11]$. The major characteristics of MLM are faster reaction (<30 days) and fineness (of 1.91 to $6.58 \mu \mathrm{m}$ ) [19, 10, 11]. The MLM can present themselves as particles pelletized, as the granulated micronized calcite (GMC) and granulated micronized dolomite (GMD), or in suspension with water (fluid), as the carbonated suspension (CS) [12, 10, 11].

Therefore, the understanding of the MLM effects application on soils with variable charge, as Inceptisol, will allow the development of rational strategies for acidity control. We hypotheses that, in soils with high buffering power and variable charge, the MLM applied in the surface and without incorporation can be more efficient than $\mathrm{DL}$ concern to increase and keep $\mathrm{pH}$ and base saturation $(\mathrm{V})$ values below the point of placement. The objective of this study was to evaluate the $\mathrm{pH}$ and $\mathrm{V}$ values along of the 45 months as a result from surface application (without incorporation) of liming materials in the soil profile under NT.

\section{MATERIAL AND METHODS}

The trial experiment was carried out in a Typic Distrudept (Inceptisol), in Palmeira, Paraná, Brazil, during Jun/2012 to Mar/2016. The local weather is Cfb (humid subtropical climate), according to Köppen-Geiger classification and the accumulate rainfall during experimental period (2012 to 2016) was of $6524.8 \mathrm{~mm}$. This area was managed under NT the last 15 years for soybean (grain production) and black oat (cover crop) during, respectively, the summer and winter season. At the beginning of the experiment in the $0-20 \mathrm{~cm}$ layer showed the following attributes [21]: $\mathrm{pH}\left(\mathrm{CaCl}_{2} 0.01 \mathrm{~mL} \cdot \mathrm{L}^{-1}-1: 2.5\right)$ of 4.3 , cation exchangeable capacity (CEC) of $145.6 \mathrm{mmol}_{\mathrm{c}} \mathrm{dm}^{-3}, \mathrm{~V}$ of $29.0 \%$, organic carbon (C) of $21.0 \mathrm{~g} \mathrm{dm}^{-3}, 1.24 ; 200.0$ and $255.2 \mathrm{~g} \mathrm{~kg}^{-1} \mathrm{of}$ the clay, silt and sandy, and $544.8 \mathrm{~g} \mathrm{dm}^{-3}$ of bulk density. The $\mathrm{pH}$ and $\mathrm{V}$ values of the layers $0-5,5-10,10-$ 20, 20-40 and 40-60 cm are being presented in the results as zero time. The CEC values of the layers $0-5$, $5-10,10-20,20-40$ and $40-60 \mathrm{~cm}$ is of 145,$8 ; 149,3 ; 143,6 ; 129,5$ and $124,5 \mathrm{mmol}_{\mathrm{c}} \mathrm{dm}^{-3}$, respectively. And, the $C$ values of the layers $0-5,5-10,10-20,20-40$ and $40-60 \mathrm{~cm}$ is of 28,$0 ; 21,0 ; 17,5 ; 18,0$ and $15,0 \mathrm{~g} \mathrm{dm}^{-3}$, respectively.

The experimental design employed was the randomized complete block in split-plot with four replications. In the plots $\left(384 \mathrm{~m}^{2}\right)$ were studied the dolomitic limestone (DL) and three micronized liming material (MLM) - granulated micronized calcite (GMC), granulated micronized dolomite (GMD) and carbonated suspension (CS). In the subplots $\left(96 \mathrm{~m}^{2}\right)$ the treatments were the control $(\mathrm{V}=0 \%)$ plus three doses of liming material aiming to increase the $\mathrm{V}$ to 50,70 and $90 \%$. The liming requirement was performed by the method of elevation of soil base saturation. The doses are $\mathrm{V}$ estimated. The liming materials were applied in total area, on the soil surface, without incorporation, once in jun/2012.

The effective calcium carbonate equivalent (ECC) of DL, GMC, GMD and CS was of 952.0, 962.7, 1006.5 and $770.0 \mathrm{~g} \mathrm{~kg}^{-1}$, respectively. The fineness factor (FF) value adopted for the MLM was of $1000 \mathrm{~g} \mathrm{~kg}^{-1}$ and for the DL was of $942.8 \mathrm{~g} \mathrm{~kg}^{-1}$ [10]. The GMC and GMD were pelletized lime, the CS was fluid lime (density is $1.89 \mathrm{~kg} \mathrm{dm}^{-3}$ ) and DL is powder lime (Figure 1). The doses aiming to increase of $V$ to 50,70 and $90 \%$ was obtained through of the equations was suggested by current methodology [7]. The doses applied of DL were $3.22,6.28$ and $9.34 \mathrm{Mg} \mathrm{ha}^{-1}$ to increase of $\mathrm{V}$ to 50,70 and $90 \%$, respectively; of GMC were 3.18, 6.21 and $9.23 \mathrm{Mg} \mathrm{ha}^{-1}$ to increase of $\mathrm{V}$ to 50,70 and $90 \%$, respectively; of GMD were 3.05, 5.94 and $8.83 \mathrm{Mg} \mathrm{ha}^{-1}$ to increase of $\mathrm{V}$ to 50,70 and $90 \%$, respectively; of CS were $3.98,7.76$ and $11.54 \mathrm{Mg} \mathrm{ha}^{-1}$ to increase of $\mathrm{V}$ to 50,70 and $90 \%$, respectively.

After the liming material applications were the experimental area was cropped with wheat (2012 and 2014), soybean (2012/13 and 2014/15), black oat (2013 and 2015) and maize (2013/14 and 2015/16). During the experimental period (Jun/2012 to Mar/2016), no liming material was applied, and the accumulate rainfall was $6524.8 \mathrm{~mm}$.

The nutrients inputs via fertilizers during the experimental period were 686,700 and $538 \mathrm{~kg} \mathrm{ha}^{-1}$ of $\mathrm{N}$ (as urea or as monoammonium phosphate), $\mathrm{P}_{2} \mathrm{O}_{5}$ (as single or triple superphosphate, or monoammonium 
phosphate) and $\mathrm{K}_{2} \mathrm{O}$ (as potassium chloride), respectively. The common agronomic practices used regionally for adequate crops development were employed.

The aleatory soil samples from 0-5, 5-10, 10-20, 20-40 and 40-60 cm were sampled by auger and dutch auger. Twelve simple samples were collected for performed a composite sample, in each layer of the subplot. The soil was sampled in 0 (at the beginning of the experiment), 5 (after the harvest of wheat 2012), 15 (after the harvest of soybean 2012/13), 28 (after the harvest of maize 2013/14), 37 (after the harvest of soybean 2014/15) and 45 (after the harvest of maize 2015/16) months after surface application of liming materials.

These samples were taken to the laboratory, dried in an oven at $40^{\circ} \mathrm{C}$ with forced air circulation over a period of 48 hours, ground and sieved in a $2.0 \mathrm{~mm}$ mesh sieve. Afterwards, $\mathrm{pH}$, exchangeable-Ca, $\mathrm{Mg}$ and $\mathrm{K}$ values was performed according to regional methods [21]. The $\mathrm{pH}$ value was determined in a $0.01 \mathrm{~mol} \mathrm{~L}^{-1}$ $\mathrm{CaCl}_{2}$ solution using a 1:2.5 (v:v) soil-to-solution ratio suspension and after was determined $\mathrm{H}+\mathrm{Al}$ with buffer solution SMP. The exchangeable-Ca and Mg values were determined in a $1.0 \mathrm{~mol} \mathrm{~L}^{-1}$ potassium chloride $(\mathrm{KCl})$ solution and titration using a standard $0.025 \mathrm{~mol} \mathrm{~L}^{-1}$ EDTA (Ethylenediaminetetraacetic acid). The exchangeable-K value was determined in Mehlich-1 $\left(0.05\right.$ mol L-1 chloride acid $(\mathrm{HCl})$ and $0.0125 \mathrm{~mol} \mathrm{~L}^{-1}$ sulfuric acid $\left(\mathrm{H}_{2} \mathrm{SO}_{4}\right)$ ) solution. The $\mathrm{V}$ was calculated by the relationship between the $\mathrm{Ca}, \mathrm{Mg}$ and $\mathrm{K}$ exchangeable values sum and cation exchange capacity (in $\mathrm{pH}=7.0$ ) [12].

Statistical analysis was performed used the computer program SAS Version 9.1.2 [23]. The variance analysis was carried out using the PROC GLM command and Tukey test $(p<0.05)$ to averages the liming materials (DL, GMC, GMD and CS). The analysis of regression was carried out using the PROC REG command to adjust the dose (to increase $\mathrm{V}$ to 50,70 and $90 \%$ besides to the control treatment) of each liming material and least significant difference (LSD) to compare the liming materials. The analysis of profile was carried out using the PROC GLM and REAPEATED command procedures to measure the effects of doses and liming materials over time $(0,5,15,28,37$ and 45 months).

\section{RESULTS}

(Table 1) There were interactions between liming materials, doses and periods after application for $\mathrm{pH}$ and $\mathrm{V}$ values. (Figure 2) In the control treatment there was increase of the $\mathrm{pH}$, in the all layers, along the time. However, the application of liming materials resulted in the $\mathrm{pH}$ changes just in the $0-5 \mathrm{~cm}$ layer than in others layers. In the $0-5 \mathrm{~cm}$ layer, all the doses of liming materials increased and remained the $\mathrm{pH}$ along the time, when compared with the control treatment.

(Figure 2) In the $0-5 \mathrm{~cm}$ layer, the $\mathrm{pH}$ increased and remained as from 28 months after application of $\mathrm{DL}$ in the dose $\mathrm{V}$ to $50 \%$. Being that, after 45 months, the $\mathrm{pH}$ measured was of 5.7 (the biggest $\mathrm{pH}$ for $\mathrm{DL}$ ). Already for MLM, the $\mathrm{pH}$ increased and remained as from 5 months of application in the dose $\mathrm{V}$ to $50 \%$. Whereas the highest $\mathrm{pH}$ was observed, in the $0-5 \mathrm{~cm}$ layer, 28 months after the application of MLM in the dose $\mathrm{V}$ to $50 \%$. These $\mathrm{pH}$ values were of $6.2,5.6$ and 6.1 to GMC, GMD and CS, respectively. Already, the $\mathrm{pH}$, after 45 months, were of 5.0, 5.4 and 5.5 to GMC, GMD and CS, respectively.

(Figure 2) The $\mathrm{pH}$ increased and remained during 5 up to 34 months of liming materials application in the dose $\mathrm{V}$ to $70 \%$ and in the $0-5 \mathrm{~cm}$ layer. However, the major increased in the $\mathrm{pH}$ were observed for GMC, GMD and CS than for DL. Already, the highest pH observed was 23 and 11 months after application of DL $(\mathrm{pH}=6.0)$ and $\mathrm{GMC}(\mathrm{pH}=6.4)$, respectively. And, the $\mathrm{pH}$, after 45 months, were of 5.0 and 4.8 to $\mathrm{DL}$ and GMC, respectively. The highest $\mathrm{pH}$ was observed after 5 months of GMD and CS application and were of 6.1 and 6.7 , respectively, both in the dose $\mathrm{V}$ to $70 \%$. After 45 months, the $\mathrm{pH}$ was of 5.4 and 5.5 to $\mathrm{DL}$ and GMC, respectively.

(Figure 2) Yet, in the $0-5 \mathrm{~cm}$ layer, the $\mathrm{pH}$ was increased and remained as from 5 months of MLM application in the dose $\mathrm{V}$ to $90 \%$. And, the increased in the $\mathrm{pH}$ were observed in the following order GMC < $\mathrm{GMD}<\mathrm{CS}<\mathrm{DL}$. Yet after 5 months, the highest $\mathrm{pH}$ values were of 5.7, 6.9, 6.5 and 6.9 to DL, GMC, GMD and CS, respectively. Already, after 45 months of DL, GMC, GMD and CS application in the dose to $90 \%$, the $\mathrm{pH}$ was of 5.5, 5.9, 5.1 and 5.5, respectively.

(Figure 3) The $\mathrm{V}$ in control treatment and in the all layers was increased along the time. However, after the application of liming material doses, the more variations in the $V$ occurred in the $0-5 \mathrm{~cm}$ layer than 5-60 $\mathrm{cm}$ layer. In the $0-5 \mathrm{~cm}$ layer, the $\mathrm{V}$ increased and remained of 23 up to 45 months of DL application in the dose to $50 \%$. Besides, the V obtained after 45 months after application of DL was of $44 \%$ more than V estimated. Yet, in the $0-5 \mathrm{~cm}$ layer, the $\mathrm{V}$ increased and remained as from 5 months after application of MLM in the dose to $50 \%$. Being that, the highest $\mathrm{V}$ in the dose to $50 \%$ was observed 28 months after application of GMC (V obtained was $58 \%$ more than V estimated) and after 34 months of GMD and CS application (V 
obtained was of 38 and $52 \%$ more than $V$ estimated, respectively). Already, the $\mathrm{V}$ obtained, after 45 months, by GMC was $42 \%$ and by GMD and CS was $30 \%$ more than the $V$ estimated $50 \%$.

(Figure 3) The V, in the $0-5 \mathrm{~cm}$ layer, increased and remained of 5 up to 34 months after application of $\mathrm{DL}$ and $\mathrm{GMC}$ in the dose $\mathrm{V}$ to $70 \%$. Already, the highest $\mathrm{V}$ obtained was observed 28 months after the application of DL and GMC in the order of 2 and $14 \%$ more than $V$ estimated, respectively. Besides, the $V$ obtained, after 45 months and in the $0-5 \mathrm{~cm}$ layer, by DL and GMC, for both, it was reached $82 \%$ of the V estimated. And, the only treatment that the $\mathrm{V}$ obtained equal the estimated of $70 \%$, was the GMC after 34 months. Still in the $0-5 \mathrm{~cm}$ layer, the $V$ increased and remained as from 5 months of GMD and CS application in the dose $\mathrm{V}$ to $70 \%$. The highest $\mathrm{V}$ obtained was observed 23 and 34 months after application of GMD and $\mathrm{CS}$, in the order of $14 \%$ more than V estimated, for both. Already, the V obtained, after 45 months, by GMD and CS, was reached $97 \%$ of the $\mathrm{V}$ estimated of $70 \%$. (Figure 3 ) The $\mathrm{V}$, in the $0-5 \mathrm{~cm}$ layer, increased and remained as from 5 months after application of all liming materials in the dose $\mathrm{V}$ to $90 \%$. The highest $\mathrm{V}$ obtained, was observed 34 months of DL and GMD application, both reached $88 \%$ of $\mathrm{V}$ estimated. Already, the $\mathrm{V}$ obtained, after 45 months, by DL and GMD reached 73 and $65 \%$ of $\mathrm{V}$ estimated, respectively. Besides, the highest $\mathrm{V}$ was observed 28 months after application of GMC and CS, both reached $93 \%$ of $\mathrm{V}$ estimated. Already, the $V$ obtained, after 45 months and in the $0-5 \mathrm{~cm}$ layer, by GMC and CS, both reached $82 \%$ of the V estimated of $90 \%$.

(Figure 4) The $\mathrm{pH}$ was more influenced by doses of liming material in the $0-5 \mathrm{~cm}$ layer. The linear increases the $\mathrm{pH}$ was observed of 5 up to 34 months of application of liming materials, except for 28 months. Thus, the higher $\mathrm{pH}$ was observed in the dose $\mathrm{V}$ to $90 \%$ after 5 months of DL and GMC application; after 11 months of all liming materials application, after 28 months of GMC, GMD and CS application; and after 34 months of DL and GMC application. The increase $\mathrm{pH}$ occurred 28 months after application of $\mathrm{DL}$ in the doses $\mathrm{V}$ to $50-70 \%$.

(Figure 5) The $V$ was influenced by doses of liming material up to $20 \mathrm{~cm}$ depth than $20-60 \mathrm{~cm}$. In the 0 $5 \mathrm{~cm}$ layer, higher $\mathrm{V}$ was observed in the dose $\mathrm{V}$ to $90 \%$ after 5, 23, 34 and 45 months of DL, GMD, GMC and CS application, respectively. In the $0-5 \mathrm{~cm}$ layer and in the dose $\mathrm{V}$ to $50-70 \%$, higher $\mathrm{V}$ was observed after 5 months of GMC, GMD and CS application; after 11 months of all liming material application; after 28 months of DL, GMC and CS application; after 34 months of CS application; and after 45 months of GMD application. Already, in the 5-10 cm layer, higher $\mathrm{V}$ was observed in the dose $\mathrm{V}$ to $50-70 \%$ after 5 and 28 months of DL application. And, in the 10-20 cm layer, higher $V$ was observed in the dose $V$ to $50-70 \%$ after 11 months of CS application. Besides, after 5 months of GMC application, in the $10-20 \mathrm{~cm}$ layer, higher $\mathrm{V}$ value was observed in the dose $\mathrm{V}$ to $90 \%$.

\section{Figures, Tables and Schemes}
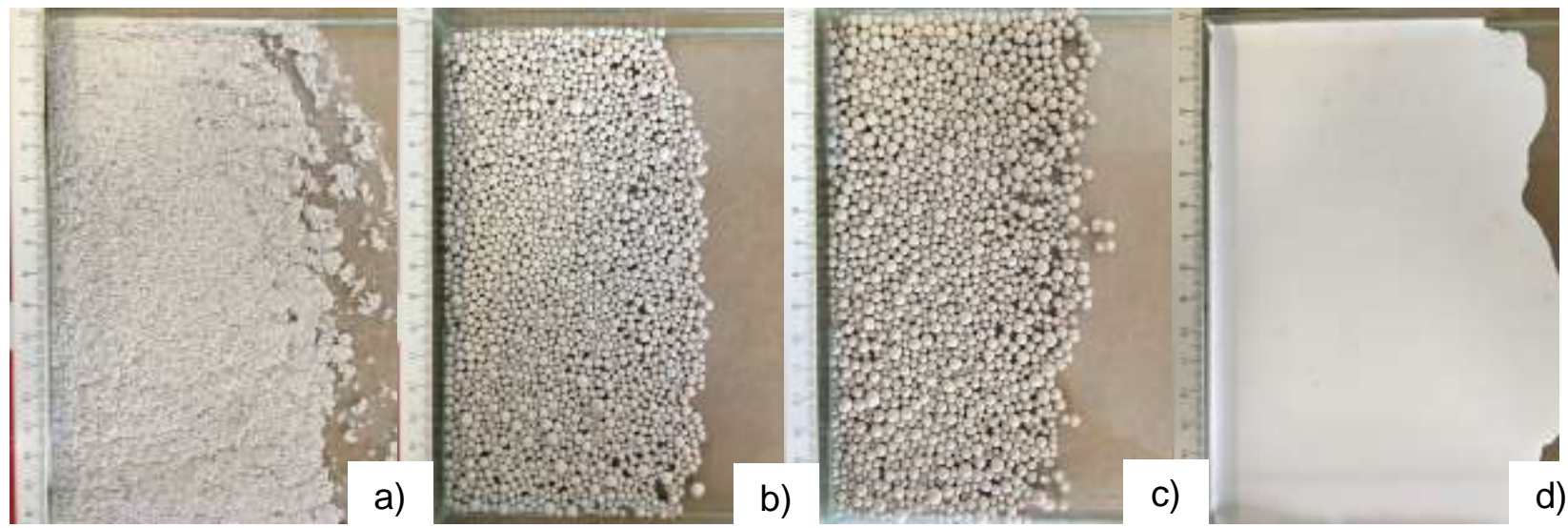

Figure 1. Granules size $(\mathrm{cm})$ and arrangement of dolomitic limestone (DL) (a), granulated micronized calcite (GMC) (b), granulated micronized dolomite (GMD) (c) and carbonated suspension (CS) (d). 

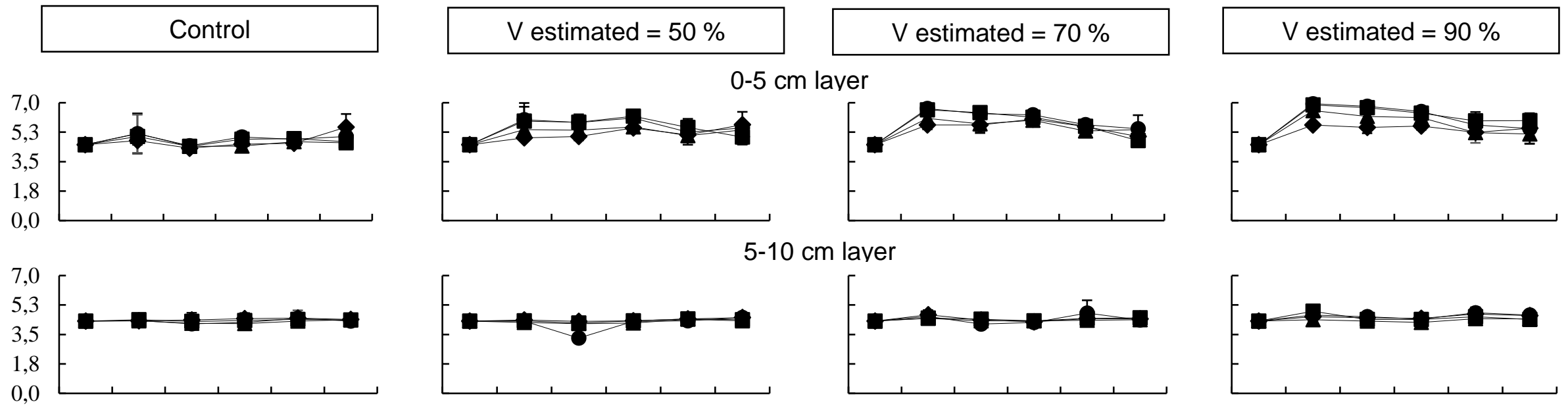

5-10 cm laver
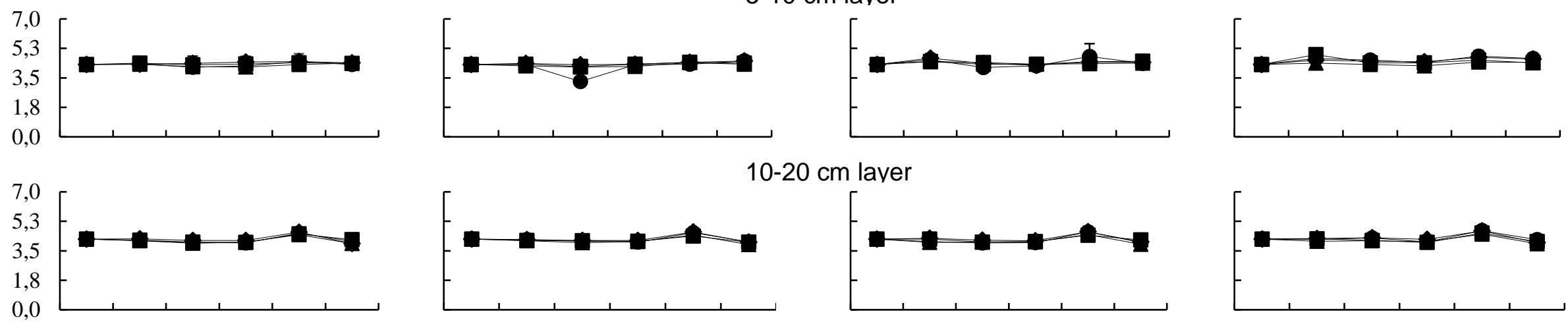

$10-20 \mathrm{~cm}$ laver
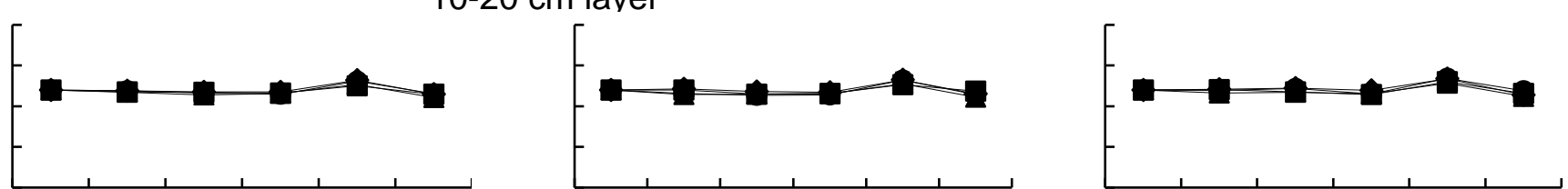

20-40 cm laver
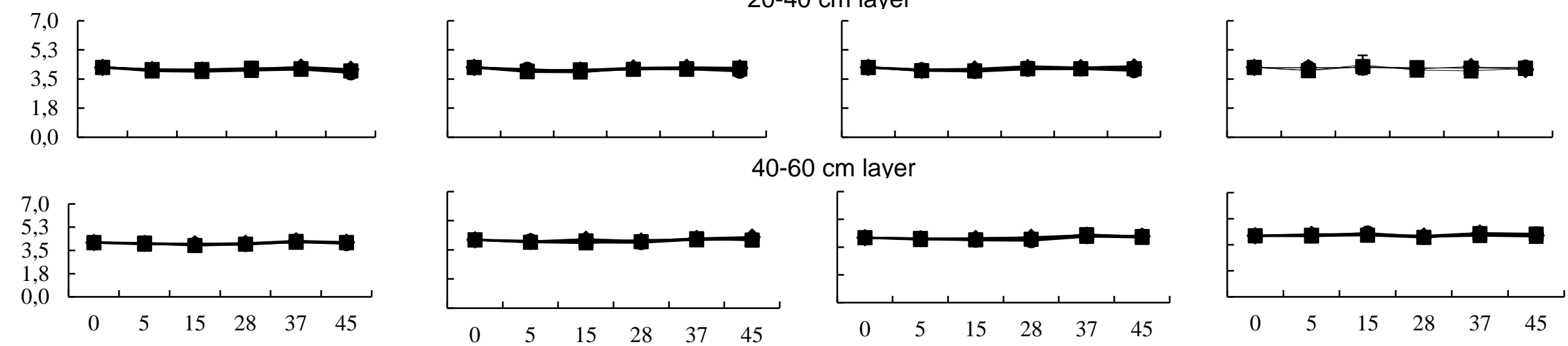

Months after application of each liming material

Figure 2. $\mathrm{pH}$ values (in $\mathrm{CaCl}_{2} 0.01 \mathrm{~mol} \mathrm{~L}^{-1}$ ) of a Typic Distrudept ( $n=16 \pm$ standard deviation), after $0,5,15,28,37$ and 45 months after the surface application of liming materials in the doses aiming the increase of the soil base saturation ( $\mathrm{V}$ estimated) to 50,70 and $90 \%$ besides control treatment, in each soil layer. ( $\$$ )

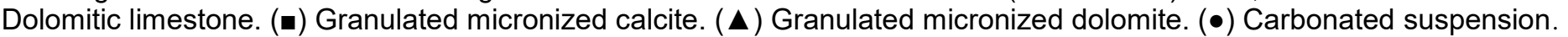



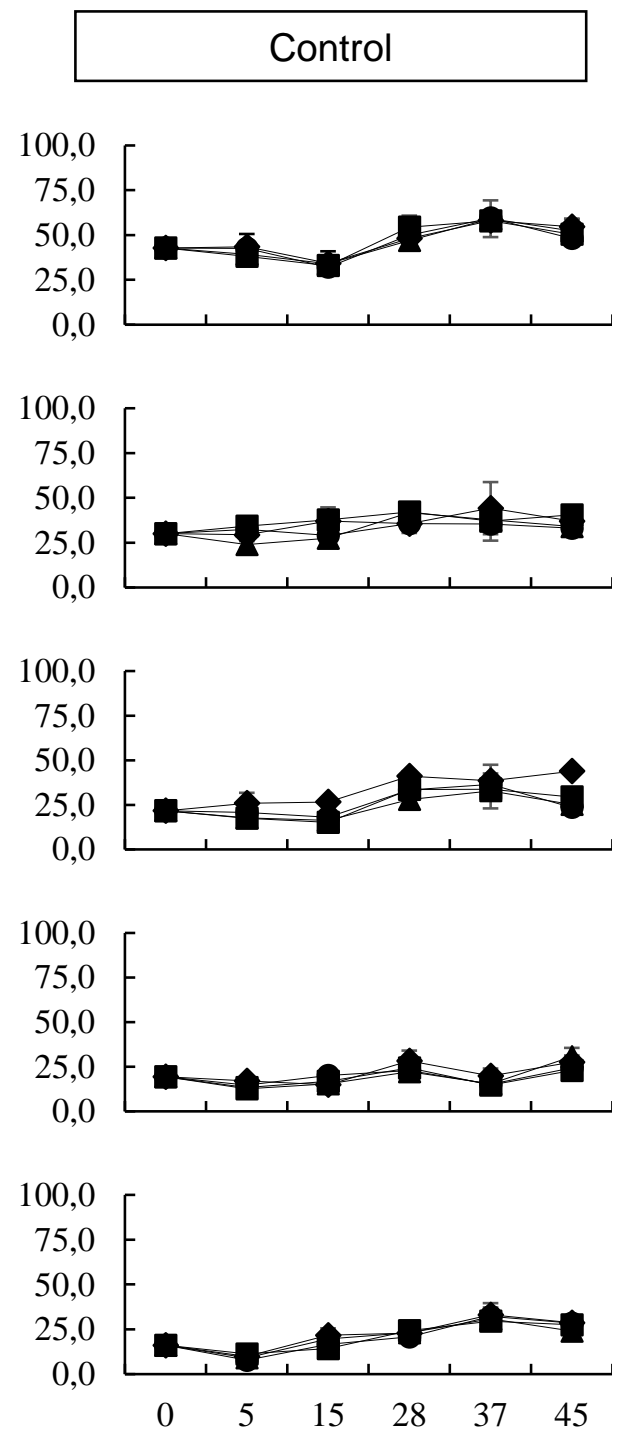
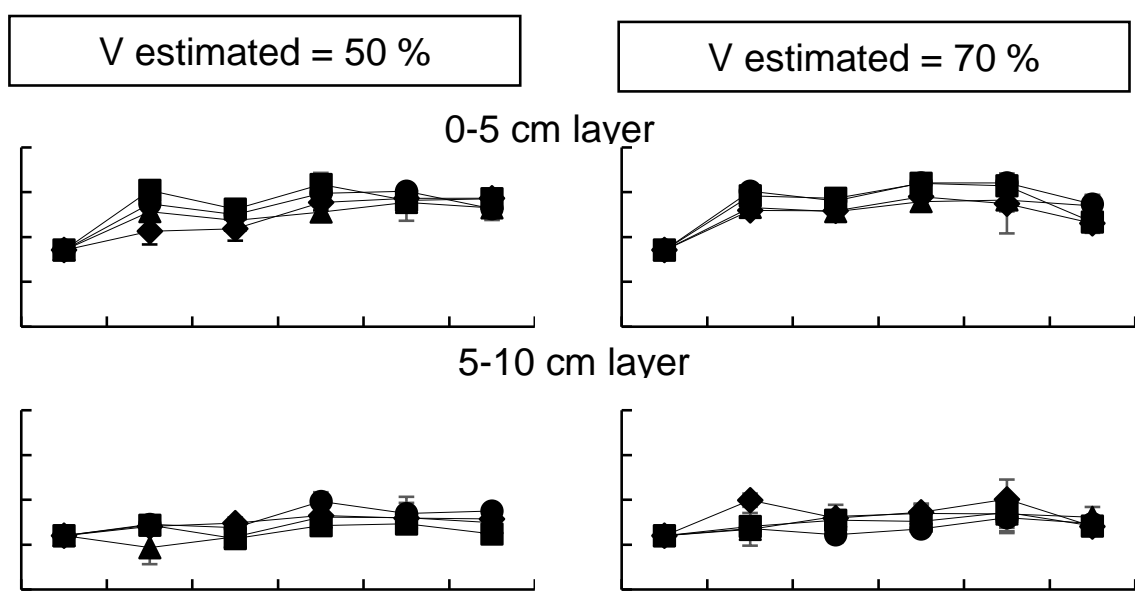

$10-20 \mathrm{~cm}$ laver
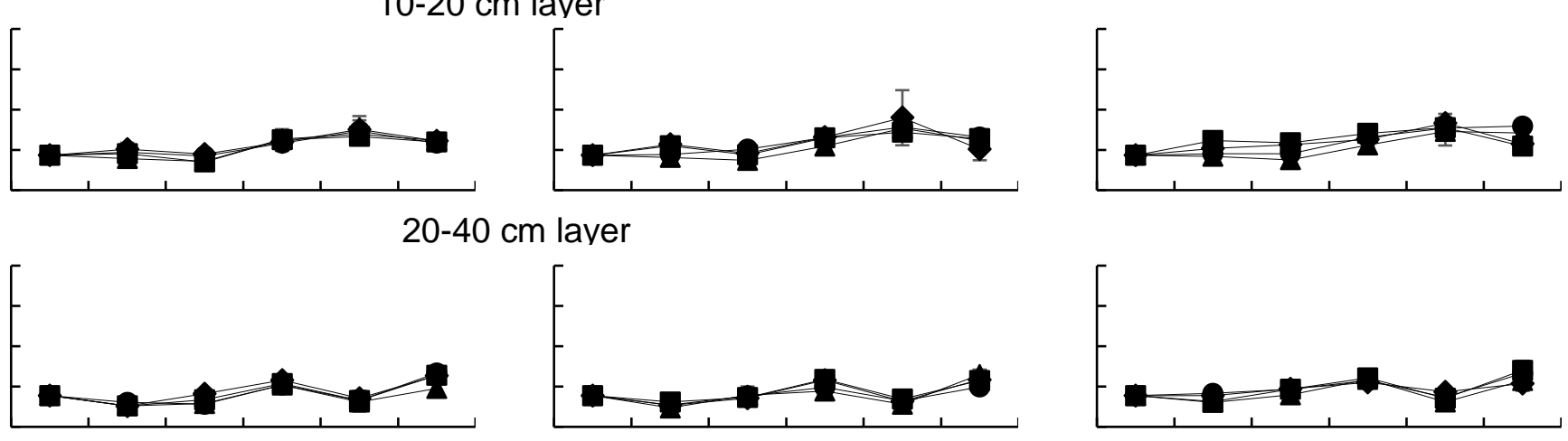

40-60 cm laver

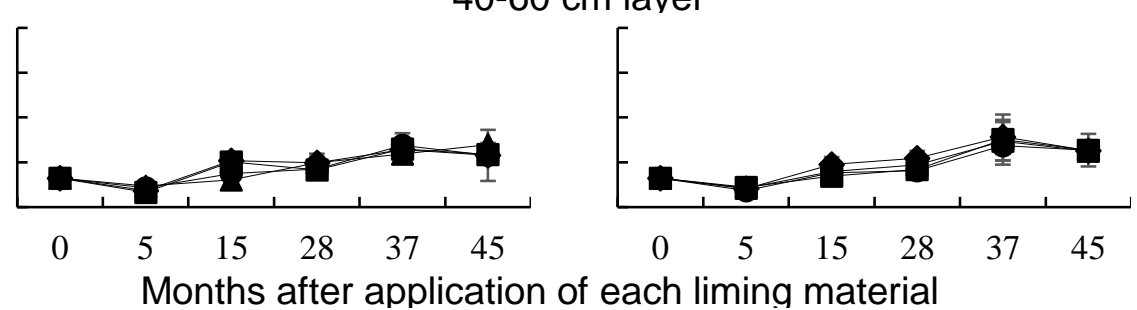

V estimated $=90 \%$
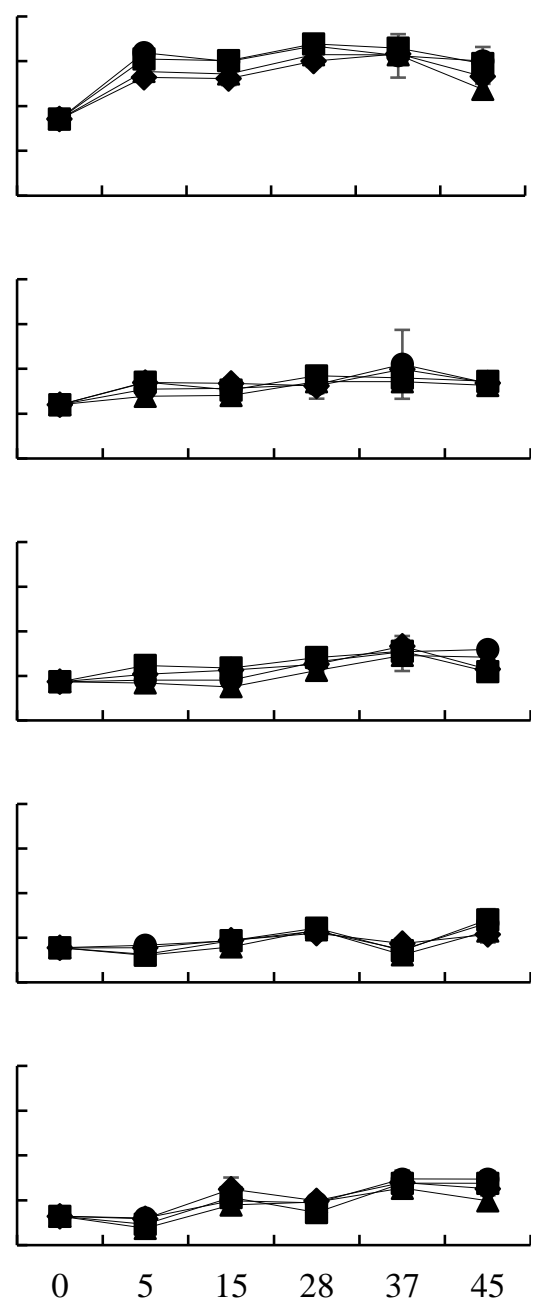

Figure 3. Soil base saturation (V), \% ( $n=16 \pm$ standard deviation) of a Typic Distrudept, after $0,5,15,28,37$ and 45 months after the surface application of liming materials in the doses aiming the increase of the soil base saturation ( $\mathrm{V}$ estimated) to 50,70 and $90 \%$ besides control treatment, in each soil layer. ( $\$$ )

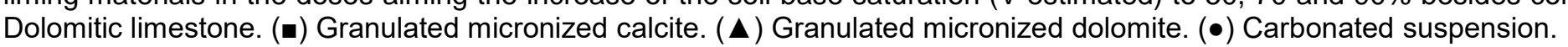




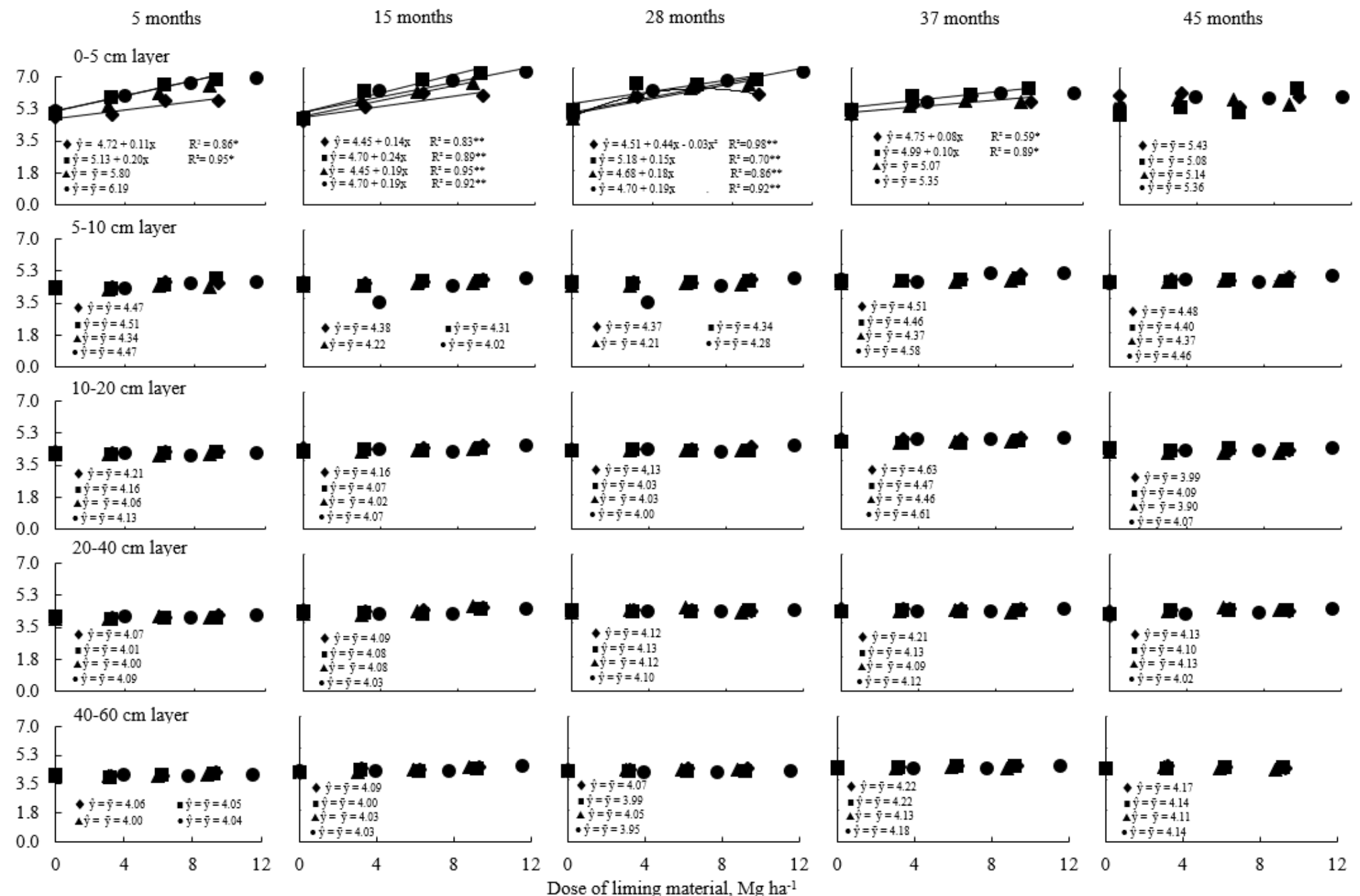

Figure 4. $\mathrm{pH}$ values $(\mathrm{n}=4)$ of a Typic Distrudept, after $5,15,28,37$ and 45 months after the surface application of liming materials in the doses aiming the increase of the soil base saturation (V estimated) to 50,70 and $90 \%$ besides control treatment, in deep layer. ( $\bullet$ ) Dolomitic limestone. (₫) Granulated micronized calcite. ( $\mathbf{\Delta}$ ) Granulated micronized dolomite. $(\bullet)$ Carbonated suspension. Vertical bars indicate the least significant difference (LSD). ${ }^{*}: P<0.05 .{ }^{* *}: P<0.01$. 
5 months

15 months
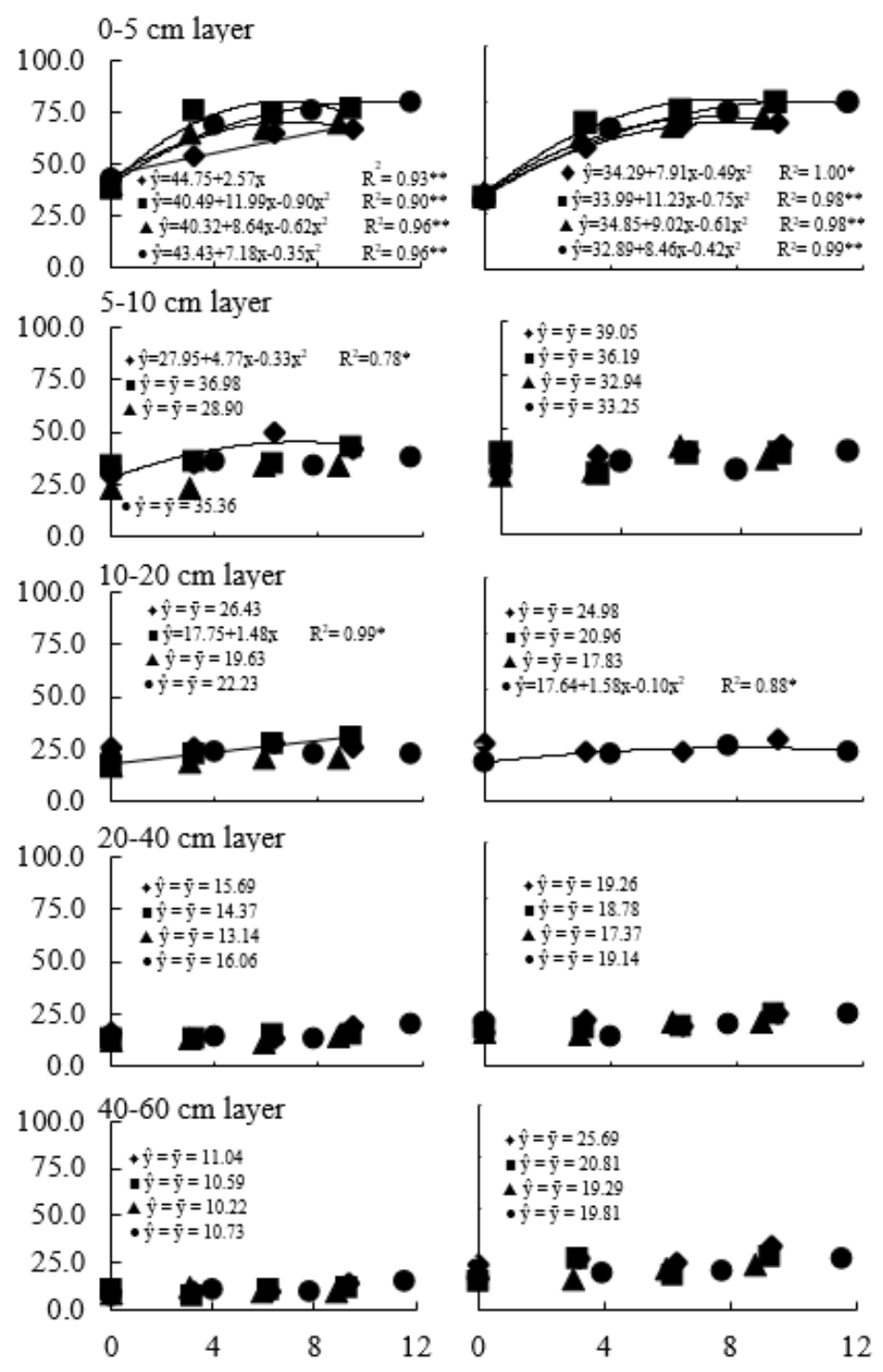

28 months
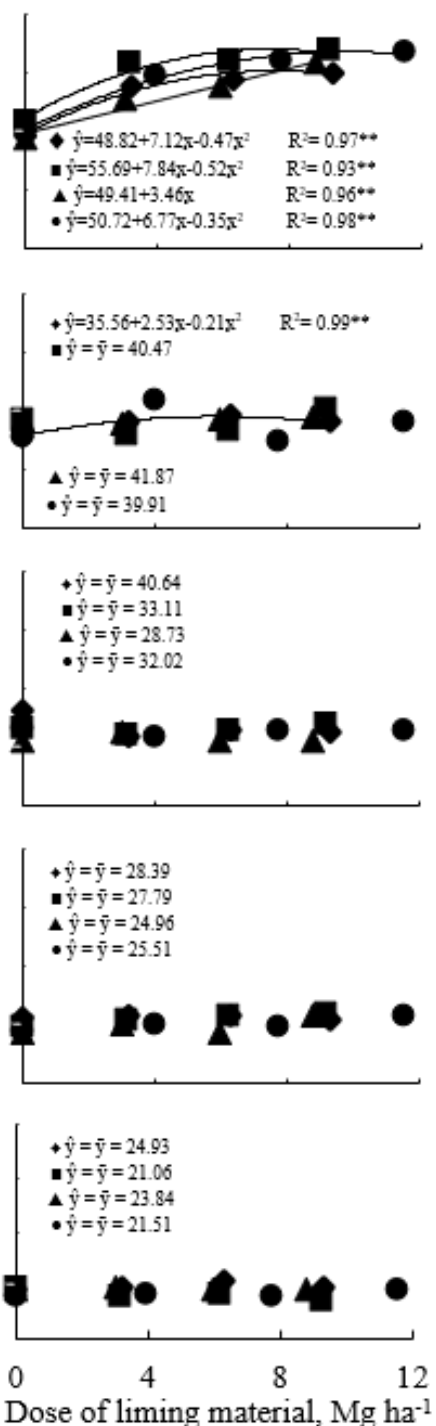

37 months

45 months
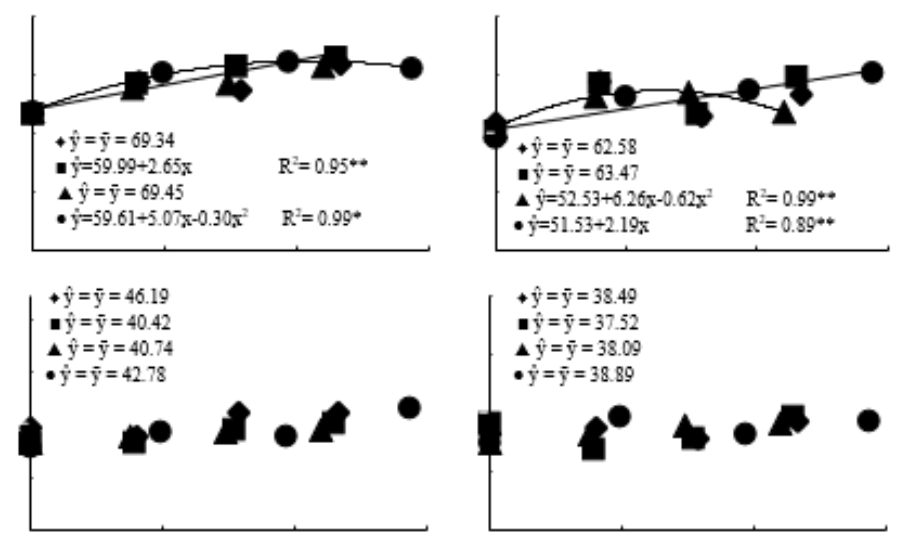
$\hat{y}=\hat{y}=\bar{y}=37.52$
$\hat{y}=\hat{y}=3809$

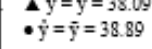
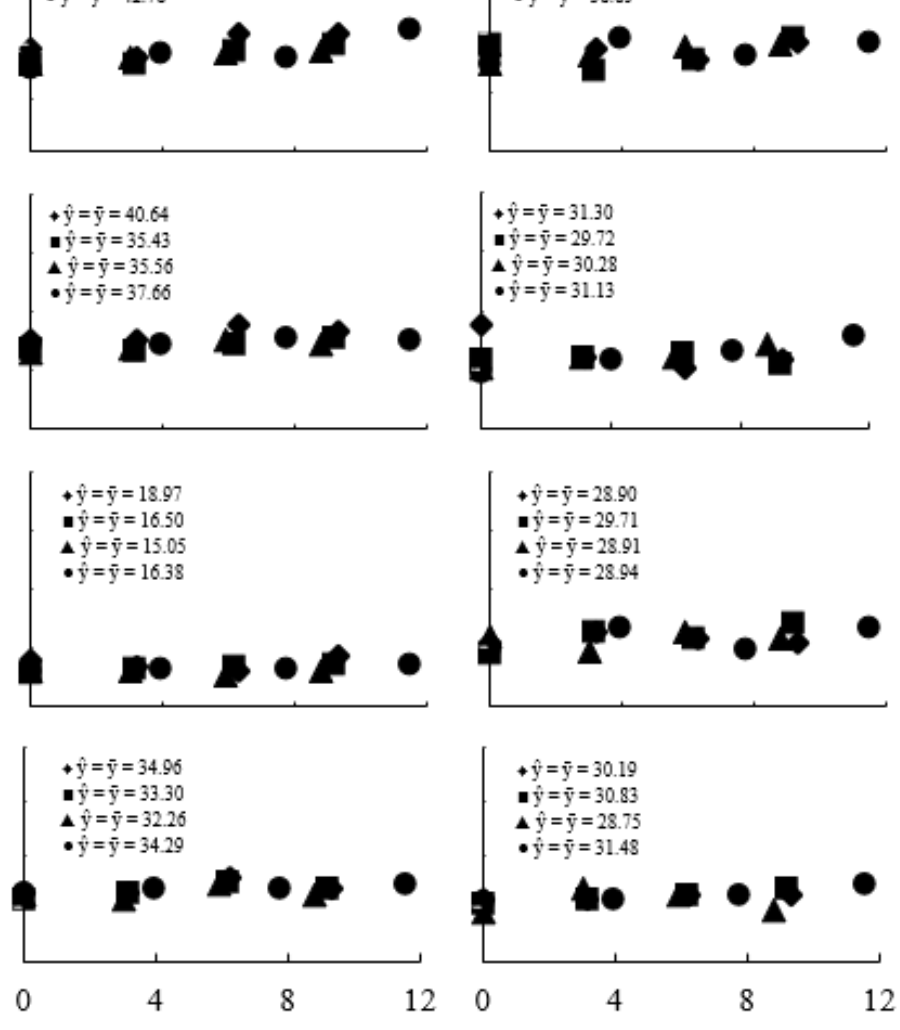

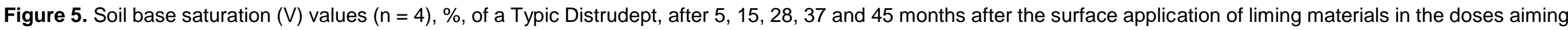

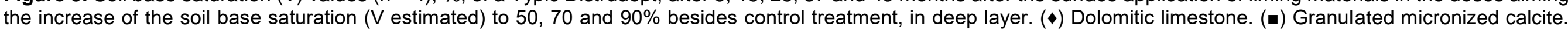
$(\boldsymbol{\Delta})$ Granulated micronized dolomite. $(\bullet)$ Carbonated suspension. Vertical bars indicate the least significant difference $(L S D) .{ }^{*}$ : $P<0.05$. ${ }^{\star \star}$ : $P<0.01$. 
Table 1. ANOVA significance for soil $\mathrm{pH}$ and base saturation (V).

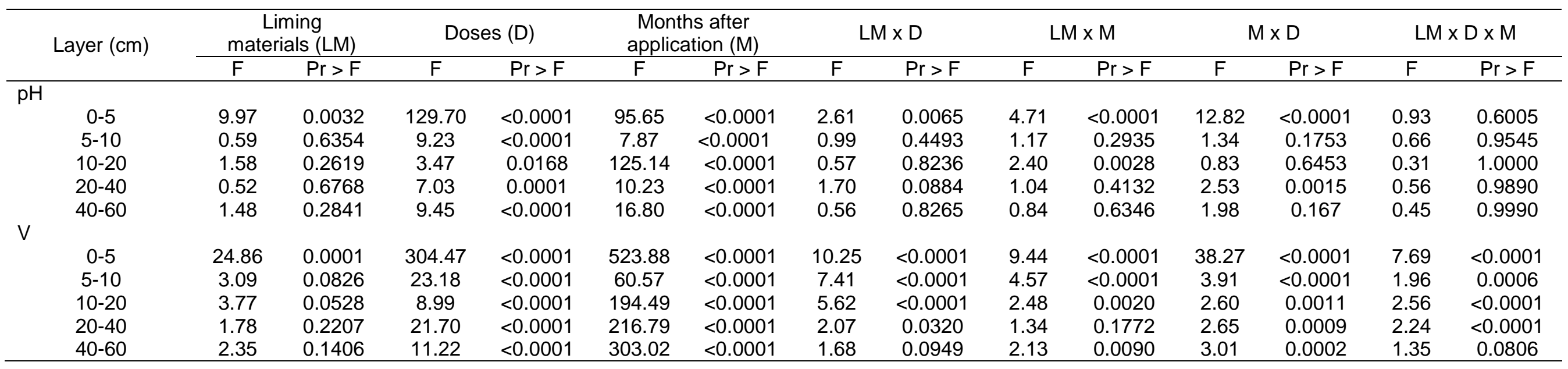




\section{DISCUSSION}

The MLM (GMC, GMD and CS) increased the $\mathrm{pH}$ and $\mathrm{V}$ as from 5 months of your application while the DL increased as from 28 months of your application, in all doses applied (Figure 2 to 5 ). This fact shows that, the MLM presented faster reaction and higher responsiveness than DL, in soil with high buffering power and variable charge under NT, under field conditions. Similar results also were observed in soils under controlled conditions, where the MLM are able to increase the $\mathrm{pH}$ and the $\mathrm{V}$ in the first month of application $[10,11]$. Therefore, in short-term, the MLM can be strategic more efficient to soil acidity control and then, reduce loss of crops yield. These results, also point to differences of Typic Distrudept with others soils, as the Oxisol under NT, whom the DL (with $840 \mathrm{~g} \mathrm{~kg}^{-1}$ of ECC) reacted after 48 months of application [15]. And also, as the Typic Hapludox under NT, whom the DL (with $710 \mathrm{~g} \mathrm{~kg}^{-1}$ of ECC) reacted after 12 months of application [9]. However, the highest $\mathrm{pH}$ and $\mathrm{V}$ observed along the time, was only 28 months of MLM application and 45 months of DL application (Figure 2 to 5). Begging that, after 28 months of MLM application there was slight decrease in the $\mathrm{pH}$ and $\mathrm{V}$, until 45 months (Figure 2 to 5). Hence, we concluded that, the MLM presented lower residual effect than DL.

All the major increased in the $\mathrm{pH}$ and $\mathrm{V}$ occurred more in the $0-5 \mathrm{~cm}$ layer than 5-60 $\mathrm{cm}$ layer, for all the liming materials and doses applied (Figure 2 to 5). This fact suggests that, the reaction of liming material applied in a Typic Distrudept (high buffering power and variable charge) under NT, occur only in the surface layer and not below the point of placement. Even though the MLM present fineness particles much lower than DL (MLM of 1.91 to $6.58 \mu \mathrm{m}$ and DL of $269 \mu \mathrm{m}$ ) this fact not favored your reaction in deep layers (5-60 $\mathrm{cm})$. In others soils, as the Haplic Umbisol, the reaction of DL (878 g kg-1 of ECC) with fineness particle (< $0.25 \mu \mathrm{m}$ ) was much faster than with $\mathrm{DL}$ of coarsest particle $(2-4 \mathrm{~mm})$, during 36 months and 0-20 cm layer [1]. Already, the absence of liming material effect in 5-60 cm layer can be attributed the following factors that (i) the soil presented higher potential acidity [22], (ii) the dissolution/dissociation as far from acidity zone and reaction time [26]; (ii) subsoil $\mathrm{pH}$ is adequate [12], (iii) the neutralization of aluminum $\left(\mathrm{Al}^{3+}\right)$ and of hydrogen $\left(\mathrm{H}^{+}\right)$on soil functional groups is limited [26], (iv) the soil buffering power is strongly by $\mathrm{Al}$ and iron (Fe) oxides [8], (v) lower water infiltration via macroporos [2] and (vi) lower adsorption/desorption of cations by organic anions soluble [17].

Also, in Typic Distrudept, can occur the reprecipitation of carbonate due to decrease of partial pressure of $\mathrm{CO}_{2}$ (by microbial activity) and increase of solute concentration, limiting the acidity control only in $0-5 \mathrm{~cm}$ layer [3]. This layer may have occurred increase of microbial activity by liming material, favoring the organic matter mineralization and the decrease of the carbon stocks (less $\mathrm{CO}_{2}$ ) [20].

The majority of Brazil, especially in the Paraná State, the liming requirement by $V$ is calculated for $0-20$ $\mathrm{cm}$ layer of soil in conventional tillage, but this also is used for NT [24]. However, in NT, with surface application and without incorporation of liming materials, the $V$ estimated is not reached, across the $0-20 \mathrm{~cm}$ layer. But, only, in some part of 0-20 cm layers, as the $0-5 \mathrm{~cm}$ layer. All the major increased in the $V$ occurred more in the $0-5 \mathrm{~cm}$ layer than 5-60 cm layer, for all the liming materials and doses applied (Figures 3 and 5). For the MLM in the dose of $\mathrm{V}$ to $50 \%$, the highest $\mathrm{V}$ observed along the time as much as the $\mathrm{V}$ after 45 months of application, it was of $\mathrm{V}$ obtained $>\mathrm{V}$ estimated, approximately $40 \%$ greater. Already, in the dose of $\mathrm{V}$ to $70 \%$, the highest $\mathrm{V}$ observed, along the time, it was of $\mathrm{V}$ obtained $>\mathrm{V}$ estimated, approximately $10 \%$ greater. Yet, in the dose of $\mathrm{V}$ to $70 \%$, the $\mathrm{V}$ after 45 months of application was of $\mathrm{V}$ obtained $<\mathrm{V}$ estimated, approximately $20 \%$ smaller. For the MLM in the dose of $\mathrm{V}$ to $90 \%$, the highest $\mathrm{V}$ observed along the time as much as the $\mathrm{V}$ after 45 months of application, was of $\mathrm{V}$ obtained < V estimated, approximately $80 \%$ smaller. This fact was stronger in MLM than DL. Begging that, among the MLM, the GMC was the only where $\mathrm{V}$ obtained equal the $\mathrm{V}$ estimated of $70 \%$ (Figures 3 and 5). Therefore, the gap between the $\mathrm{V}$ estimated and measured is smaller in soil treatment with MLM than DL. This way, the MLM present greater assurance that what was applied really reacted. But, when the $\mathrm{V}$ obtained is higher than $\mathrm{V}$ estimated, can be occur a problem with the overliming in the $\mathrm{pH}$ in surface layer. This fact was common with surface application of CS in all the doses (Figures 3 and 5). The overliming in the $\mathrm{pH}$ may cause, in short-time, micronutrient unavailability [12]. Therefore, in short-term, the MLM can be strategic more efficient to increase and remain the $\mathrm{V}$ and then, reduce loss of crops yield.

As from results obtained, the doses of all liming materials more recommended is aiming $\mathrm{V}$ between 50 and $70 \%$ for a Typic Distrudept under NT (Figure 2 to 5 ). Therefore, the dose aiming V over $70 \%$ and below $50 \%$ will not occur interesting results. In these doses and among the MLM, the GMC and CS were more efficient than others liming materials studied with regard to increase of $\mathrm{pH}$ and $\mathrm{V}$. However, for Typic Distrudept the dose aiming $\vee$ to $70 \%$, commonly used in Oxisol [6], may not be appropriate. 


\section{CONCLUSION}

The micronized liming material increase and keeps $\mathrm{pH}$ and $\mathrm{V}$ values, only in the $0-5 \mathrm{~cm}$ layer, during 5 up to 45 months after surface application, without incorporation, in a Typic Distrudept under no-tillage. However, the fineness particles of micronized liming material do not favor the soil reaction in the $5-60 \mathrm{~cm}$ layer. The doses of all liming materials more recommended is aiming base saturation between 50 and $70 \%$ for a Typic Distrudept. The gap between the soil base saturation estimated and obtained is smaller in soil treatment with micronized liming material than dolomitic lime, manly in the $0-5 \mathrm{~cm}$ layer. Therefore, the liming materials, applied superficially and without incorporation, were not efficient to increase the $\mathrm{pH}$ and $\mathrm{V}$ values below the point of placement, in soils high buffering power and variable charge, as the Typic Distrudept.

Acknowledgments: The author would like to show gratitude for the support of CNPq, CAPES, Omya do Brasil, and for the use of the research facilities of the Multi-User Laboratories Complex (C-LABMU/PROPESP/UEPG) and all students of agronomy course (UEPG) who assisted in the soil sampling and chemical analysis.

Conflicts of Interest: The authors declare no conflict of interest.

\section{REFERENCES}

1. Álvarez E, Viadé A, Fernández-Marcos ML. Effect of liming with different sized limestone on the forms of aluminium in a Galician soil (NW Spain). Geoderma. 2009; 152:1-8.

2. Amaral AS, Anghinoni I, Deschamps FC. Resíduos de plantas de cobertura e mobilidade dos produtos da dissolução do calcário aplicado na superfície do solo. Rev Bras Ciênc Solo. 2004a; 28:115-23.

3. Amaral AS, Anghinoni I, Deschamps FC. Resíduos de plantas de cobertura e mobilidade dos produtos da dissolução do calcário aplicado na superfície do solo. Rev Bras Ciênc Solo. 2004b; 28:115-23.

4. Bolan NS, Rowarth J, de la Luz Mora M, Adriano D, Curtin D. Biological transformation and bioavailability of nutrient elements in acid soils as affected by liming, in: Naidu, R. (Ed.), Chemical Bioavailability in Terrestrial Environments. Elsevier B.V. 2008.

5. Caires EF, Alleoni LRF, Cambri MA, Barth G. Surface application of lime for crop grain production under a no-till system. Agron J. 2005; 97:791-8.

6. Caires EF, Haliski A, Bini AR, Scharr DA. Surface liming and nitrogen fertilization for crop grain production under no-till management in Brazil. Eur J Agron. 2015. 66:41-53.

7. Cantarella H, Van Raij B, Quaggio JA. Soil and plant analyses for lime and fertilizer recommendations in Brazil. Commun Soil Sci Plan. 1998; 29:1691-1706.

8. Cho S, Dinwoodie G, Fu Y, Abboud S, Turchenek L. An assessment of long-term soil acidification trends in Alberta, Canada. Ecol Indic. 2019; 98:712-22.

9. Crusciol CAC, Marques RR, Carmeis Filho ACA, Soratto RP, Costa CHM, Ferrari Neto J, Castro GSA, Pariz CM, de Castilhos AM. Annual crop rotation of tropical pastures with no-till soil as affected by lime surface application. Eur J Agron. 2016; 80:88-104.

10. Dos Santos JA, Da Fonseca AF, Zocco D, Vieira I. Special liming materials for acidity control of soils with variable charge. Afr J Agric Res. 2016b. 11:2920-36.

11. Dos Santos JA, Da Fonseca AF, Zocco D, Vieira I. Exchangeable cations and available phosphorus in soils with variable charge after application of special liming materials. Afr J Agric Res. 2016a; 11:2744-60.

12. Havlin JL, Tisdale SL, Nelson WL, Beaton, JD. Soil Fertility and Nutrient Management: An Introduction to Nutrient Management, 8th ed. Pearson, Upper Saddle River, New Jersey. 2014.

13. Hue NV. Alleviating soil acidity with crop Residues. Soil Sci. 2011; 176:543-9.

14. Hue NV. Development, impacts and management of soil acidity in Hawaii. J Haw Pac Agri. 2008; 15:14-26.

15. Joris HAW, Caires EF, Scharr DA, Bini AR, Haliski A. Liming in the conversion from degraded pastureland to a notill cropping system in Southern Brazil. Soil Till Res. 2016; 162:68-77.

16. Lawrence GB, Burns DA, Riva-Murray K. A new look at liming as an approach to accelerate recovery from acidic deposition effects. Sci Total Environ. 2016; 562:35-46.

17. Miyazawa M, Pavan MA, Franchini JC. Evaluation of plant residues on the mobility of surface applied lime. Braz Arch Biol Technol. 2002; 45:251-6.

18. Oliveira EL, Pavan MA. Control of soil acidity in no-tillage system for soybean production. Soil Till Res. 1996; 38:4757.

19. Oliveira LR, Cunha HP, Silva NM, Pádua IPM. Chemical and mineralogical characterization and soil reactivity of brazilian waste limestones. APCBEE Procedia, 2014; 9:8-12.

20. Paradelo R, Virto I., Chenu C. Net effect of liming on soil organic carbon stocks: A review. Agric Ecosyst Environ., 2015; 202:98-107.

21. Pavan MA, Bloch MF, Zempulski HC, Miyazawa M, Zocoler DC. Manual de análise química do solo e controle de qualidade, Instituto Agronômico do Paraná, Londrina. 1992.

22. Rheinheimer DS, Tiecher T, Gonzatto R, Zafar M, Brunetto G. Residual effect of surface-applied lime on soil acidity properties in a longterm experiment under no-till in a Southern Brazilian sandy Ultisol. Geoderma. 2018; 313:7-16. 
23. SAS System. SAS Institute Inc. SAS OnlineDoc® 9.1.2. Cary, NC: SAS Institute. 2004.

24. SBCS - Sociedade Brasileira de Ciência do Solo. Manual de Adubação e Calagem para o Estado do Paraná. Sociedade Brasileira de Ciência do Solo. Núcleo Estadual Paraná. 2017

25. Valentinuzzi F, Mimmo T, Cesco S, Mamun SA, Santner J, Hoefer C, Oburger E, Robinson B, Lehto N. The effect of lime on the rhizosphere processes and elemental uptake of white lupin. Environ Exper Bot. 2015; 118:85-94.

26. Vargas JPR, Santos DR, Bastos MC, Schaefer G, Parisi PB. Application forms and types of soil acidity corrective: Changes in depth chemical attributes in long term period experiment. Soil Till Res., 2019; 185:47-60.

(C) 2020 by the authors. Submitted for possible open access publication under the terms and conditions of the Creative Commons Attribution (CC BY NC) license (https://creativecommons.org/licenses/by-nc/4.0/). 